\title{
Project-based learning in science-teacher pedagogical practicum: the role of emotional experiences in building preservice teachers' competencies
}

\author{
Dina Tsybulsky ${ }^{1 *}$ (1) and Yulia Muchnik-Rozanov ${ }^{1,2}$
}

\begin{abstract}
The study investigated preservice teachers' (PST) emotional experiences, teaching competencies, and the connection between the two over the course of a pedagogical practicum conducted using a project-based learning (PBL) approach. The study addressed the following research questions: (a) Which emotional experiences accompanied PSTs' PBL-based pedagogical practicum?

(b) Of the competencies for implementing PBL that the PSTs developed during the practicum, which did they consider using as part of their classroom practices in the future? (c) Is there a connection between PSTs' emotional experiences and their self-reported competencies for implementing PBL in their classroom practices? Participants were 16 preservice teachers in their first year in the teacher-education program for teaching sciences. Data were collected from reflective reports, submitted th the end of the first and second semesters, thereby addressing the middle and final stages of the PBL-based practicum, and were analyzed using three complementary methodologies: content, linguistic, and statistical analyses. The findings indicate that, as portrayed by the participants, PSTs'

immersion in the PBL-based practicum was accompanied by both positive and negative emotional experiences. While immersed in the PBL practicum, the PSTs described themselves as developing various teaching competencies for implementing PBL in the classroom. It was also found that the positive emotional experiences outnumbered the negative, and this predominance was positively linked to the development of the PSTs' competencies.
\end{abstract}

Keywords: Science-teacher education, Preservice teachers, Pedagogical competencies, Pedagogical practicum, Emotional experiences, Project-based learning, Elementary school

\section{Introduction}

Project-Based Learning (PBL) has become widely used in science education as a promising teaching approach to promote learning in its cognitive, social, and emotional aspects. PBL enhances deep collaborative multidisciplinary learning, engages learners in authentic practices, and "builds an iterative culture where learners always prototype, reflect, redesign, revise, and evaluate, which are

\footnotetext{
* Correspondence: dinatsy@technion.ac.il

${ }^{1}$ Faculty of Education in Science and Technology, Technion, Haifa, Israel Full list of author information is available at the end of the article
}

considered the core practices of PBL" (Grossman et al, 2019, p.44).

Therefore, teacher-education frameworks have begun to integrate PBL into their preparation programs. Studies in the field indicate that the PBL approach has a positive effect on preservice teachers (PSTs) in terms of their problem-solving skills, learning achievements, and their views regarding the teaching profession (Alrajeh, 2021; Kokotsaki et al., 2016).

Despite increasing documentation of the advantages of integrating PBL in teacher education, only a few studies have focused on PBL in the context of pedagogical 
practicum. This scarcity in the reported research can be viewed as a significant lacuna since pedagogical practicum constitutes a key component of teacher education in terms of preparing future teachers for fieldwork (Ohana, 2004; Bhattacharyya et al., 2009) and is a major source of empowering experiences (Beeth \& Adadan, 2006; Lawson et al., 2015; Varma \& Hanuscin, 2008). The authors' previous work has demonstrated that PBLbased practicum positively affects PSTs since it offers meaningful social, cognitive, and introspective experiences that lead to the development of their professional identity, improvement of attitudes towards the principles of PBL pedagogy, and implementation of PBL in their teaching practices (Tsybulsky, 2019; Tsybulsky et al., 2020; Tsybulsky \& Muchnik-Rozanov, 2019; Tsybulsky \& Oz, 2019).

Pursuing the same line of research, the current study seeks to explore emotional aspects of PSTs' experiences during a PBL-based practicum and to examine the ways in which these emotional experiences contribute to building the competencies necessary for integrating PBL into their teaching practices. We conceptualized competencies as an integrated set of knowledge and understanding, skills, abilities, and beliefs (Mohamed et al., 2017; Pantić \& Wubbels, 2010; Struyven \& De Meyst, 2010; Tang et al., 2020).

\section{Theoretical background \\ Project based learning}

PBL pedagogy belongs to the broader context of inquirybased learning (Loyens et al., 2012) and it has been reported to be highly beneficial for tertiary education by several authors. PBL is viewed as a promising approach for building twenty-first-century skills since, by its nature, it fosters critical thinking, problem-solving skills, teamwork, and leadership (Chu et al., 2017; Krajcik \& Czerniak, 2018; Miller \& Krajcik, 2019; Virtue \& Hinnant-Crawford, 2019). PBL also has high potential for increasing equity in STEM education since it emphasizes learning in contexts relevant to students and their daily lives (Craig \& Marshall, 2019). Additionally, Almulla (2020) found that the PBL leads to students' engagement by promoting, sharing, and discussing knowledge and experiences.

In a typical PBL process, students develop a product for a particular target audience by working through a given problem and then evaluate both the project and the development process (Kokotsaki et al., 2016; Krajcik \& Shin, 2013). PBL includes the following essential elements: (1) Begins with a driving question or challenge that provides context and drives instruction; (2) Aligns with significant content learning goals, (3) Incorporates twenty-first century skills; (4) Facilitates in-depth inquiry that allows the student to explore the content; (5)
Multiple opportunities providing student choice and voice; (6) Provides multiple opportunities for selfcritique and assessment, and.

(7) Results in presenting a final product to a community audience (Craig \& Marshall, 2019).

The PBL approach was chosen for this study due to its recognized positive impact on teacher education. As such, it was found that PSTs who had been immersed in a PBL environment acquired pedagogical and content knowledge, enhanced understanding, communication skills, and self-esteem (Frank \& Barzilai, 2004) as well as decision-making abilities (Frank \& Barzilai, 2004; Mettas \& Constantinou, 2008). Implementing the PBL approach into teacher education tends to affect the novice teachers' decision to integrate it into their personal pedagogical repertoire when teaching in the field (Kavanagh \& Rainey, 2017; Reisman et al., 2018).

Several studies have reported significant gains in PSTs' academic achievements (Baran \& Maskan, 2011; Partikasari \& Nurwita, 2019; Sahin \& Top, 2015) and teacher self-efficacy (Choi et al., 2019) following the implementation of a PBL process. There are indications that the PBL process positively affects the development of PSTs' professional identity (Kokotsaki et al., 2016; Marshall et al., 2010; Tsybulsky et al., 2020; Tsybulsky \& Muchnik-Rozanov, 2019) as well as their views regarding the teaching profession (Lavy \& Shriki, 2008).

One of the aspects neglected in educational research on PBL is the emotional experiences of PSTs when implementing a PBL process. To date, the literature has reported on the satisfying and positive experiences of PSTs, associated with the teamwork that the PBL process includes (Simons \& Baeten, 2016), as well as the emotional support (e.g., Gardiner \& Robinson, 2009), enhanced professional learning (e.g., educational skills) and personal development (e.g., increased confidence; King, 2006).

This study examines the participants' emotional experiences during and after applying the PBL pedagogy in the course of their pedagogical practicum, to gain insight into the process by which PSTs develop the necessary know-how and competencies to implement PBL into their teaching.

\section{Pedagogical practicum and emotions}

The role of emotions in teaching is considered an important one (Beauchamp \& Thomas, 2009; Gkonou \& Miller, 2020), and emotional knowledge may be seen as an integral part of teacher knowledge (Zembylas, 2001, 2007). Both positive and negative emotions may shed light on how PSTs interpret their learning experiences (Bellocchi et al., 2014) and develop their understanding of themselves and of their role as teachers (Meyer, 2009; Yuan \& Lee, 2015). 
Moreover, understanding PSTs' emotions experienced while studying towards becoming teachers is deemed vital, since these emotions tend to reflect on the learning process during the teacher-education stage, as well as on PSTs' experiences during the pedagogical practicum (Anttila et al., 2016, 2017).

PSTs experience both positive and negative emotions during the pedagogical practicum. The most frequent positive emotions are joy, happiness, enthusiasm, and satisfaction and the most frequent negative emotions are anxiety, anger, despair, insecurity, frustration, worry, and stress (Agudo \& Azzaro, 2018; Méndez López, 2020). Most positive emotions can be traced to inter-personal relationships with students (Cowie, 2011; Nguyen, 2014), the students' active performance (Méndez López, 2020), the achievement of PSTs' goals, intrinsic motivation towards the teaching profession, self-fulfillment, and pride in becoming a teacher (Kihwele \& Chuma, 2020). In addition, a high level of self-efficacy predicts positive emotions of joy and pride (Burić et al., 2020). Feeling pride and triumph was also found to be associated with not giving up and overcoming numerous challenges (Bellocchi \& Ritchie, 2015). These positive emotions may lead PSTs to feel higher levels of confidence in pedagogical reasoning and an overall feeling of comfort regarding their role in the classroom (Grey, 2020). Moreover, experiencing positive emotions motivates PSTs to be innovative and creative and makes them more persistent in pursuing positive results (Kihwele \& Chuma, 2020).

To date, despite the fact that understanding the role of emotions in the teacher-education process has emerged as a research-worthy goal (Bellocchi et al., 2013; Bellocchi et al., 2014; Hong et al., 2011; Ritchie et al., 2011, 2013), no research has explored the role of emotions in building PSTs' competencies during practicum. Our work seeks to fill this gap in the context of a PBL-based practicum.

\section{Theoretical framework}

We use Systemic Functional Linguistics (SFL) theory to conceptualize and explore the participants' emotional experiences as portrayed in their reflective narratives. According to the SFL framework, emotional experiences are manifested in language behaviour via certain lexical choices (Halliday \& Matthiessen, 2004). Linguistically, emotional experiences are characterized by employing various kinds of intensification while reflecting on and describing these experiences (Halliday, 1994; Halliday \& Matthiessen, 2004; Kupferberg et al., 2013).

We also employ the Broaden-and-Build theory of positive emotions proposed by Fredrickson (Fredrickson, 2004) to conceptualize the role of positive emotional experiences in building pedagogical competencies. The theory describes "the form and function of a subset of positive emotions, including joy, interest, contentment, and love" (Fredrickson, 1998, p. 300). The theory states that positive emotional experiences can broaden one's awareness and encourage novelty in thinking and actions even in the presence of difficulties and challenges, building up skills and personal resources (Fredrickson, 2001; Fredrickson \& Branigan, 2005). In addition, according to the theory, positive emotional experiences contribute to individuals' wellbeing by constituting "efficient antidotes for the lingering effects of negative emotions" (Fredrickson et al., 2000, p. 239).

\section{Methods}

\section{Research questions}

(a) Which emotional experiences accompanied PSTs' PBL-based pedagogical practicum?

(b) Of the competencies for implementing PBL that the PSTs developed during the practicum, which did they consider using as part of their classroom practices in the future?

(c) Is there a connection between PSTs' emotional experiences and their self-reported competencies for implementing PBL in their classroom practices?

\section{The Study's context and participants Participants}

The participants of the study were 16 PSTs in their first year of studies towards a B.Ed. degree with a specialization in teaching sciences at the elementary school level. The sample consisted of men and women between the ages of 20 and 24 years, who resided in the county's southern region and came from a low-tomidlevel socioeconomic background.

\section{Context}

The participants in the current study were enrolled in the year-long pedagogical practicum, which consisted of two key components: a didactics workshop that accompanied PSTs' clinical experience and the clinical experience at schools itself. Both the workshop and clinical experience were conducted according to the PBL approach. During their clinical experience, as part of the pedagogical practicum, PSTs taught science classes to elementary school students, according to the PBL approach. This was an opportunity for them to experience the PBL approach as teachers. The accompanying didactics workshop was run in the college setting and offered the PSTs the opportunity to experience the PBL approach as students.

The clinical experience was carried out in two elementary schools, teaching in third through sixth grades. These pupils were taught with the PBL science modules that PSTs had prepared, and worked on a range of 
projects tied to curriculum topics. For example, one of the third-graders' projects was dedicated to local culinary herbs and plants. The driving question was: "What makes my food so delicious and healthy?" In this project, pupils were divided into learning teams of 3-5. Each team explored a different herb or plant, focusing on its unique properties and growing conditions. The final product was to prepare a poster summarizing the pupils' findings and plant the explored herbs/plants in the schoolyard. During the final PBL event, the pupils presented their herbs/plants and posters to the audience (parents, guests, teachers, and peers).

Two PSTs were assigned to each class and were supported by instructional coaches. A total of eight instructional coaches participated in the project, and their role included the following aspects: (a). They enabled the PSTs to experience teaching in the classroom. (b). They approved the lesson plans, which had already been reviewed and approved by the lecturer who was in charge of both the practicum and the accompanying workshop; hence, the input of the instructional coaches to the lesson plans was minimal. (c). They gave the PSTs feedback after each lesson. The latter was the most significant aspect of their role, which was important given that the lecturer could not observe all of the classes at the same time (and, consequently, was present only in a portion of these).

In the framework of the pedagogical practicum, the PSTs were asked to prepare an educational project. The driving question was as follows: "How can you develop students' scientific thinking skills using various teaching methods and approaches?" Fig. 1 shows the stages of the PSTs' work on their projects.

This way, throughout the PBL-based pedagogical workshop, the participants were exposed to PBL via inquiring, planning, debating ideas, and sharing experiences in the course of teamwork in small groups of up to four PSTs. The participants experienced all the aspects of the PBL process, including peer assessment (stages 1 and 5), self-assessment (stages 2 and 4), creating products (stages $2,4,5$ ), and public presentation of the outcomes (stage 5).

\section{Ethical issues}

The participants were informed about the nature and procedure of the study and had signed an informed consent form, after receiving an explanation clarifying that their participation would be voluntary, and that their responses would remain anonymous (pseudonyms are used herein) and would have no bearing on their academic grades (PSTs were not graded for handing in reflective reports). It should be noted that the authors were not involved in teaching the PSTs.

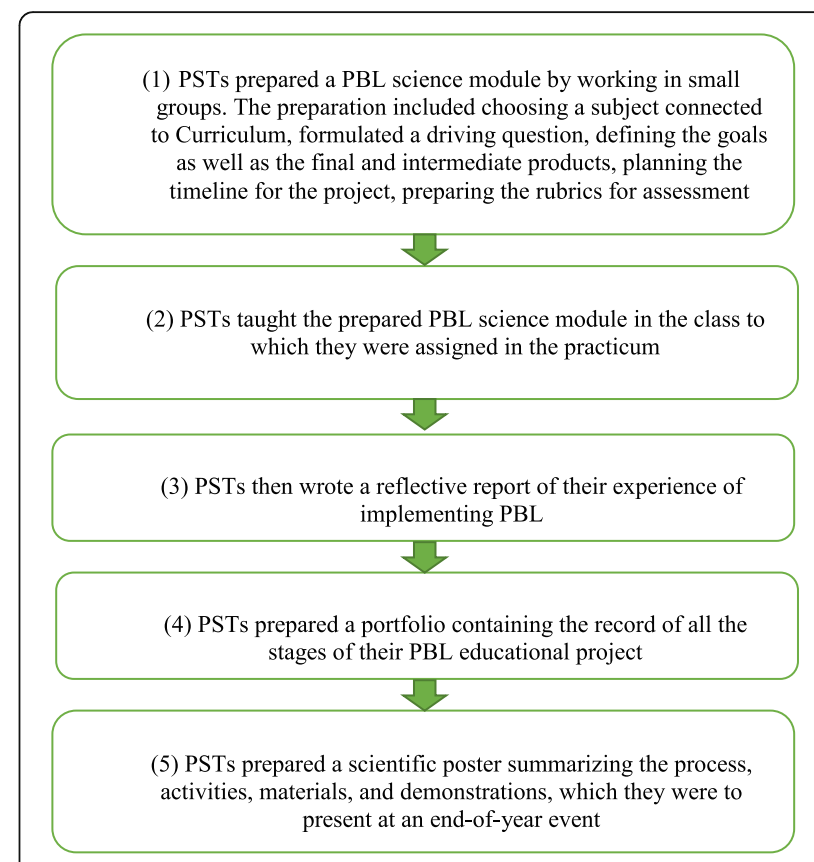

Fig. 1 The stages of PBL educational process that PSTs underwent

\section{Research approach}

The study was conducted using a mixed-methods approach for the collection and processing of data. I applied the triangulation research design in which the quantitative and qualitative research phases occur at the same time, and both methods are given equal weight (Creswell \& Plano Clark, 2007).

\section{Research tools and data collection}

The data were obtained from the PSTs' reflective reports, submitted at the end of both the first and the second semesters. It should be noted that reflective reports/ diaries are commonly used for data collection in research on teacher emotions (Bellocchi \& Ritchie, 2015; Tzifopoulos, 2020; Zembylas, 2003). This tool enables the participants to address inner issues while describing their experiences and to express and interpret their feelings throughout the reflective narratives. Overall, 32 reports were analyzed. Participants were instructed to write their reflections in a completely free manner, without any guidance or structure, and to describe, as they saw fit, their learning and teaching experiences while noting what they found particularly significant, what they felt and thought during the learning process, the difficulties encountered, what they had learned from the process, and what they would implement in their professional lives in the future.

\section{Data analysis}

The data were analyzed using three complementary methodologies: content, linguistic, and statistical 
analyses. To answer the first research question (which emotional experiences accompanied PSTs' PBL-based pedagogical practicum?), we used two complementary methods: linguistic analysis and an open content analysis. The linguistic analysis examined language choices observed across the reflective reports (Schieble et al., 2015; Trent, 2013), which made it possible to identify implicitly conveyed messages, whereas the content analysis provided an understanding of the participants' explicitly conveyed perceptions (Muchnik-Rozanov \& Tsybulsky, 2019).

Based on the SFL theory, certain adverbs indicate higher or lower intensity by emphasizing the quality of the experience, which may be "interpersonally neutral" (e.g., very, much, quite, really, completely, utterly, almost, etc.) or may "derive from some interpersonally significant scale (amazingly, awfully, unbelievably, perfectly, etc.)" (Halliday \& Matthiessen, 2004, p. 356). The effect of intensification can also be achieved through lexical reiteration, i.e., repetition of a particular lexical item in order to emphasize a given point (Buttny \& Jensen, 1995; Halliday, 1994; Halliday \& Matthiessen, 2004; Kupferberg et al., 2013). We viewed the instances of intensification as markers of meaningful emotional experiences, as opposed to those described without intensifiers. Descriptions of emotional experiences were coded when any intensifier was used, regardless of whether it conveyed an interpersonal quality, or when certain lexical items were repeated within a span of five adjacent clauses. For example, instances of emotional experiences were identified when the PSTs wrote words and expressions such as terribly, very, most, much, really, even more, indeed, a lot, so much, amazingly, plenty, more, and I can. Phrases (predominantly clauses) containing an instance of either positive or negative intensification were coded as descriptions of emotional experiences and served as the units measured in the current linguistic analysis. The total number of such phrases was calculated. In addition, a distinction between positive and negative emotional experiences was made. Descriptions of emotional experiences that could be characterized as neither positive nor negative were coded as neutral.

The content analysis was employed to code phrases that explicitly described PSTs' emotional experiences (both positive and negative). For example, phrases containing the descriptions of positive emotional experiences were coded when the participants wrote: "I liked learning," "I'm feeling very optimistic," "That's extremely encouraging," etc. The instances of phrases containing the descriptions of negative emotional experiences were coded when the PSTs wrote: "I feel like I'm trying but still failing," "I felt like there were instances in which I began to feel stressed and sometimes I lost my sense of direction," "Sometimes I felt a bit frustrated," etc.

Phrases that had been coded as describing emotional experiences, using either the linguistic or the content analysis, were merged into a single category while keeping the distinction between positive and negative emotional experiences. Then, the percentages of phrases describing positive vs. negative emotional experiences were calculated (out of the total number of the coded phrases). When the same phrase addressed an emotional experience both explicitly (revealed by content analysis) and implicitly (revealed by linguistic analysis), it was coded as one occurrence.

To answer our second research question (Of the competencies for implementing PBL that the PSTs developed during the practicum, which did they consider using as part of their classroom practices in the future?), we used the content analysis. This analysis involved several stages (Creswell \& Poth, 2016). In the first reading of the material, we selected phrases in which the PSTs referred to their competencies, i.e., their beliefs regarding their own knowledge and understanding of PBL process as well as skills and abilities to implement PBL pedagogy. In the second stage of the analysis, the selected phrases were distributed into two major content categories based on the valence attributed to the phrase in question, i.e., whether the reported phrase referred positively or negatively to the PBL competence described. Then, the percentages of phrases containing positive vs. negative reference to PSTs' competencies were calculated (out of the total number of the coded phrases classified during the second stage of the analysis). At a later stage-and along with the literature analysis-an elucidating analysis was conducted, in which the phrases that contained a positive reference to the PSTs' competencies (needed for PBL implementation), were further divided into subcategories. The selection of subcategories was done cautiously to allow for a more accurate portrayal of the explored phenomenon; subcategories that were found less relevant were dropped. Table 1 summarizes the categories and sub-categories used in the analysis of competencies.

To answer our third research question (Is there a connection between PSTs' emotional experiences and their self-reported competencies for PBL implementation?), we used Spearman's one-tailed correlation test (after quantifying the results obtained from the linguistic and open content analyses). In particular, correlations were tested between the following variables: the number of phrases describing PSTs' positive/negative emotional experiences and the number of phrases describing their self-reported developed competencies and willingness to implement PBL. 
Table 1 Competence analysis and coding method

\begin{tabular}{|c|c|c|c|}
\hline $\begin{array}{l}\text { Main } \\
\text { Categories }\end{array}$ & $\begin{array}{l}\text { Sub- } \\
\text { Categories }\end{array}$ & Coding Method & Examples \\
\hline \multirow[t]{2}{*}{$\begin{array}{l}\text { Knowledge } \\
\text { and } \\
\text { understanding }\end{array}$} & Positive & $\begin{array}{l}\text { Phrases containing positive reference to PSTs' } \\
\text { knowledge and understanding of PBL process }\end{array}$ & $\begin{array}{l}\text { In my opinion, one of the most important things that I } \\
\text { learned from the PBL process and which I will use in the } \\
\text { future is not to be afraid of group work, even when students } \\
\text { object. }\end{array}$ \\
\hline & Negative & $\begin{array}{l}\text { Phrases containing negative reference to PSTs' } \\
\text { knowledge and understanding (lack of knowledge and } \\
\text { understanding) of PBL process }\end{array}$ & $\begin{array}{l}\text { I have never studied according to this [PBL] method, so I'm } \\
\text { afraid I don't really understand how it works. }\end{array}$ \\
\hline \multirow[t]{2}{*}{$\begin{array}{l}\text { Skills and } \\
\text { abilities }\end{array}$} & Positive & $\begin{array}{l}\text { Phrases containing positive reference to PSTs' skills and } \\
\text { abilities to implement PBL in their classrooms }\end{array}$ & $\begin{array}{l}\text { After each stage, we experienced in the project, I felt my self- } \\
\text { confidence strengthening, that my lessons were significant, } \\
\text { and that my ability to teach the project was improving from } \\
\text { one lesson to the next. }\end{array}$ \\
\hline & Negative & $\begin{array}{l}\text { Phrases containing negative reference to PSTs' skills } \\
\text { and abilities (lack of skills and abilities) to implement } \\
\text { PBL in their classrooms }\end{array}$ & $\begin{array}{l}\text { I was terribly afraid that I would fail; I was afraid that I would } \\
\text { not manage to cope in front of an entire class of students or } \\
\text { convey the lesson properly. }\end{array}$ \\
\hline \multirow[t]{2}{*}{ Beliefs } & Positive & $\begin{array}{l}\text { Phrases containing positive reference to PBL as a } \\
\text { teaching approach }\end{array}$ & $\begin{array}{l}\text { PBL is innovative, breaks the routine, interesting and } \\
\text { challenging for the teacher and students, which leads to full } \\
\text { cooperation and motivation during the lesson. }\end{array}$ \\
\hline & Negative & $\begin{array}{l}\text { Phrases containing negative reference to PBL as a } \\
\text { teaching approach }\end{array}$ & $\begin{array}{l}\text { As an idea it is excellent and has many benefits, but the } \\
\text { reality knocks on the door, and the annual curriculum is based } \\
\text { on efficiency and work. It is not possible to practice PBL and, } \\
\text { at the same time, expect the pace learning to be as it is } \\
\text { defined by the Ministry of Education. }\end{array}$ \\
\hline
\end{tabular}

\section{Validity and reliability}

In the current study, validity and reliability were ensured on several levels. First, by triangulation of the research instruments, i.e., the use of several instruments to answer research questions (see explanations above). It should be noted that the content analysis was conducted by the two authors; the statistical analysis was conducted by the first author, with a Ph.D. in Science Education, while the linguistic analysis was performed by the second author, with a Ph.D. in Linguistics.

Regarding the content analysis, reliability and validity were achieved by conducting a careful review of the stages by the two researchers. Each researcher analyzed the data separately, to the best of their knowledge, and then reported the findings in a brainstorming session, which included a discussion that focused on the research questions. In cases of disagreement, the issue was further discussed until full agreement was reached, which included all team members. It should also be noted that although neither the classroom observations, the discussions with instructional coaches, nor the researchers' field journals were used for data collection purposes, they were valuable as tools for establishing the reliability of the findings.

\section{Findings}

Emotional experiences accompanying PSTs' PBL-based pedagogical practicum (RQ1)

Our analyses revealed that emotional experiences were described as both positive and negative, although the majority of them were positive. It was also clear that the number of emotional experiences increased over time and reached a pinnacle at the end of the pedagogical practicum (85\% at the end of the first semester, and $90 \%$ at the end of the second semester). Table 2 summarizes the results concerning RQ1.

The PSTs positive emotional experiences were associated with the collaborative nature of PBL (i.e., working together, supporting each other, sharing their learning experiences).

My feeling about working on the project in a group is that there is nothing better than enjoying the feeling of a team and relying on each other; joining together, we complement each other. [They say] you cannot applaud with one hand, and the same is true about group work: you share ideas and thoughts, and the outcome is spectacular. (Alina).

In terms of the PBL-based practicum stages (Fig. 1), the positive emotional experiences were related to stages 1 (preparing a module), 2 (teaching the prepared module), and 5 (presenting the educational projects at the end-of-year event). The following are excerpts from PSTs' data, which exemplify the typical positive experiences. "We were working on the PBL project and were enjoying a tremendous sense of accomplishment, especially on the day when we presented the products" (Soghud).

We learned to use the PBL approach in our pedagogy lessons and implemented what we learned in 
Table 2 Emotional experiences accrued in the course of a PBL-based pedagogical practicum: Valence and frequency of mentions

\begin{tabular}{|c|c|c|}
\hline $\begin{array}{l}\text { The Valence of Emotional } \\
\text { Experiences }\end{array}$ & $\begin{array}{l}\text { Distribution across } \\
\text { the Semesters }\end{array}$ & Example Quotes \\
\hline $\begin{array}{l}\text { Positive emotional } \\
\text { experiences }\end{array}$ & $\begin{array}{l}* 85 \% \\
* * 90 \%\end{array}$ & $\begin{array}{l}\text { Working on this project was a very significant part of the deep understanding I gained in } \\
\text { this fascinating profession and, therefore, it opened a very broad perspective for me. } \\
\text { (Natalie) } \\
\text { There is no doubt that as the year continued, this course contributed a great deal to my } \\
\text { pedagogical knowledge and was enriching. (Valerie) } \\
\text { I felt that the atmosphere in the classroom had changed, and it felt much better! (Shira) }\end{array}$ \\
\hline $\begin{array}{l}\text { Negative emotional } \\
\text { experiences }\end{array}$ & $\begin{array}{l}{ }^{*} 12 \% \\
{ }^{* *} 8 \%\end{array}$ & $\begin{array}{l}\text { Before I began studying, I had lots of fears, for example: how would I manage to stand in } \\
\text { front of the class? (Hanina) } \\
\text { I was terribly afraid that I would fail; I was afraid that I would not manage to cope in front of } \\
\text { an entire class of students or manage to convey the lesson properly. (Eden) }\end{array}$ \\
\hline Neutral emotional experiences & $\begin{array}{l}*(3 \%) \\
{ }^{* *}(2 \%)\end{array}$ & $\begin{array}{l}\text { Actually, I learned a lot about myself, and not just about myself; I learned many things about } \\
\text { the people who surrounded me. (Yaara) }\end{array}$ \\
\hline $\begin{array}{l}\text { Total number of phrases } \\
\text { referring to experiences }\end{array}$ & $\begin{array}{l}* 1153 \\
* * 1347\end{array}$ & \\
\hline
\end{tabular}

* The end of the first semester

** The end of the second semester

the classroom. Now I can hardly believe what a wonderful, significant, meaningful, fascinating, and successful (- albeit accompanied by challenges and overloaded schedules) process we experienced!! It is a good feeling of fulfillment, pride, and empowerment that fills me now. (Ina).

I'm very glad that I had the opportunity to experience the PBL as a preservice teacher. I think every future teacher should be exposed to this process the way we were. On a personal level, I enjoyed the process very much, especially because this approach enabled me to attend to each student individually, get to know them, interest them, and challenge them. ... I feel an immense sense of satisfaction and motivation to continue teaching using the PBL approach. (Shira).

These results indicate that PSTs' immersion in the PBLbased practicum was accompanied by emotional experiences, most of which were described as positive. At the same time, PSTs reflected on negative emotional experiences as well (Table 2). These negative emotional experiences were mainly associated with difficulties and obstacles during their clinical experience (Fig. 1, stage 2). 'Undoubtedly things were very difficult, but I managed to cope with it all and overcome the difficulties, regardless of the situation and despite the stress' [Keren]; 'I realised that things did not fall into place the way I wanted them to and that I had to invest time, effort, and persistence. .. '[Dan].

\section{PBL implementation competencies developed during the pedagogical practicum (RQ2)}

Findings indicate that PSTs' experiences while implementing the PBL approach were accompanied, for the most part, by positive thoughts and feelings related to their motivation, skills, and knowledge. Such positive emotions were described both at the end of the first semester (72\%) and at the end of the second semester (85\%). Furthermore, it is clear from the participants' reports that the number of positive references to developed competencies increased over time, a finding which indicates that the level of self-awareness and selfconfidence of PSTs increased as they progressed through the educational process. Negative references to the participants' capacities were related mostly to anxiety regarding the challenges they would encounter in the classroom and how they would manage the students. Table 3 summarizes the results pertaining to RQ2.

PSTs also reported that after completing the process, their self-confidence had improved and they felt more certain of their ability to lead the PBL-based lesson. "I can tell that today I am more confident than ever; I initiate [ ideas] and believe in myself and my abilities" (Hadar). "After each stage, we experienced in the project, I felt my self-confidence strengthening, that my lessons were significant, and that my ability to teach the project was improving from one lesson to the next" (Shani).

Furthermore, participants noted that through the PBL experience they had developed important teaching competencies that would help them teach PBL-based classes in the future. "A lot of what we learned was new to me and I acquired skills for working with small groups, teaching with PBL, giving students feedback, and even teaching the students how to give each other feedback" (Hanaan).

In my opinion, one of the most important things that I learned from the PBL process and which I will use in the future is not to be afraid of group work, even when students object. Collaborative work is a 
Table 3 Competencies developed in the course of a PBL-based pedagogical practicum: Frequency of mentions

\begin{tabular}{|c|c|c|}
\hline $\begin{array}{l}\text { The valence of Self-reported Developed } \\
\text { Competencies }\end{array}$ & $\begin{array}{l}\text { Distribution across } \\
\text { the Semesters }\end{array}$ & Example Quotes \\
\hline Positive references & $\begin{array}{l}{ }^{*} 72 \% \\
{ }^{* *} 85 \%\end{array}$ & $\begin{array}{l}\text { I feel that I am now able to provide guidance to the pupils as they work in } \\
\text { group format. (Lina) } \\
\text { I want to use this in my future teaching, and I feel that I now have the skills to } \\
\text { do so. (Adva) }\end{array}$ \\
\hline $\begin{array}{l}\text { Negative } \\
\text { References (absence of competencies) }\end{array}$ & $\begin{array}{l}* 28 \% \\
{ }^{*} 15 \%\end{array}$ & $\begin{array}{l}\text { Before I began studying, I had lots of fears, for example: how would I manage to } \\
\text { lead the project? (Tal) } \\
\text { I was terribly afraid that I would fail; I was afraid that I would not manage to } \\
\text { cope in front of an entire class of students or convey the lesson properly. (Eden) }\end{array}$ \\
\hline $\begin{array}{l}\text { Total number of phrases referring to self- } \\
\text { reported developed competencies }\end{array}$ & $\begin{array}{l}* 1118 \\
* * 1127\end{array}$ & \\
\hline
\end{tabular}

necessary skill for life in general and for studying in particular. I couldn't believe it when I saw students change before my very eyes, transitioning from yelling and making noise to studying. I feel that I am now able to guide students in group work for the project. (Lena).

Participants also noted that they looked forward to and felt prepared to implement certain components or educational principles of the PBL approach.

I was impressed by the novelty of the PBL approach, which introduces a change in the typical routine and is interesting and challenging for both the teacher and the students, which in turn leads to highly motivated collaboration during the lesson. I want to use this approach also in the future and I feel that I have acquired the knowledge and skills to do so, in particular, regarding the following components: conducting group work, transferring the responsibility for learning to the student, recruiting students' motivation to reach a particular outcome, giving each student individual attention, and addressing their interests and desires. (Adva).

Experiencing the PBL process taught me that even when there are changes in the lesson, they can be implemented through learning. I learned to be attentive to students and be aware of their learning process, which I wish to continue to implement in the future. I do believe that I will be able to teach in this manner, that is, enabling the students to explore and research, helping them take responsibility for their own learning, and dedicating enough time for all of these. (Tal).

We may conclude that participants mostly reported that the experience of the PBL practicum led to the development of various competencies for implementing project-based learning in the classroom.
The connection between emotional experiences and PSTs' self-reported competencies for implementing PBL in their classroom practices (RQ3)

Our findings revealed a significant correlation $(p<.01)$ between meaningful emotional experiences and PSTs' self-reported developed competencies for implementing the PBL pedagogy. In particular, the high frequency (85\% and $90 \%$ ) of the positive emotional experiences correlated with a higher frequency (72\% and 85\%) of self-reported developed competencies and willingness to implement PBL. Moreover, a significant negative correlation $(p<.01)$ was found between positive emotional experiences and self-reported lack of willingness and competencies regarding the implementation of PBL pedagogy. In other words, the high frequency $(88 \%$ and 92\%) of the positive emotional experiences coincided with a lower frequency ( $28 \%$ and $15 \%$ ) of self-reported lack of inspiration and competencies for implementing the PBL pedagogy. These correlations were found at the midyear point, as well as at the end of the academic year.

It is important to mention that the content analysis of the data revealed that in most cases, participants' referred to the development of these competencies in tandem with a reference to the positive emotional experiences (i.e., either in the same sentence or in adjacent ones).

I very much enjoyed the PBL; I learned a lot; I acquired many tools and skills, and my selfconfidence improved. Now I am certain that I am able to implement such projects in the classroom and am much less anxious about the potential difficulties, as I already know what could happen and how to address it. (Shirley).

For me, this was a very unique, successful, and enlightening experience ... I learned and internalized the PBL principles, which have become my core pedagogical guidelines and include the following: preparing the lessons, using the alternative 
assessment method (the final product), defining goals and objectives, recruiting students' participation in the preparation and learning processes, and encouraging students' creativity and motivation for learning. (Lidor).

In summary, it appears that the PBL-based practicum promotes PSTs mostly positive emotional experiences, thus providing fertile ground for the development of the necessary competencies for teaching using the PBL approach in their classrooms. As noted, both the emotions and the competencies were frequently mentioned in a single sentence or adjacent sentences. This observation further supports the link that was found between PSTs' self-reported development of PBL implementation competencies and their positive emotional experiences.

\section{Discussion}

This study aimed to examine participants' emotional experiences in the course of a PBL-based pedagogical practicum to gain insight into the role of emotional experiences by PSTs in developing the necessary knowhow and competencies to implement PBL into their teaching.

Firstly, the findings indicate that, as portrayed by the participants, PSTs' immersion in the PBL-based practicum was accompanied by both positive and negative emotional experiences. It was also found that the positive emotional experiences outnumbered the negative, mostly related to obstacles and challenges. The prevalence of positive emotional experiences enabled PSTs to overcome the difficulties by being "an efficient antidote" (Fredrickson, 2004, p.1367) to mitigate the discouraging effect of negative emotions. The predominance of perceived positive emotional experiences reported throughout the data can be explained by the fact that the reflective reports were submitted at the end of the first and second semesters, thereby addressing the middle and final stages of the PBL-based practicum, which are associated with fewer challenges or frustration and more success and satisfaction (Tsybulsky et al., 2020; Tsybulsky \& Muchnik-Rozanov, 2019; Tsybulsky \& Oz, 2019). In addition, as Timoštšuk et al. (2016) showed, positive emotions during practicum correlated with constructivist teaching strategies employed by PSTs.

Secondly, while immersed in the PBL practicum, the PSTs described themselves as developing various pedagogical competencies for implementing PBL in the classroom. This finding adds to those of previous studies, which have shown that PBL-based practicum led to the implementation of PBL pedagogical principles (e.g., inquiring, teamwork, self-, and peer assessment, creating artifacts) in teaching (Tsybulsky \& Oz, 2019). Moreover, this finding contributes to the existing literature on the topic, which has shown the positive effect of PBL-based practicum on PSTs learning to teach (e.g., Tsybulsky et al., 2020; Tsybulsky \& Muchnik-Rozanov, 2019).

Thirdly, our findings suggest that the predominance of positive emotional experiences during the PBL-based practicum is positively linked to developing the PSTs' pedagogical competencies for implementing a PBL approach in their teaching. The role of positive emotional experiences in building teaching competencies can be explained following Fredrickson's $(2001,2004)$ Broadenand-Build theory. Positive emotions stimulate PSTs' thinking and pedagogical reasoning and engage their personal resources, thereby building pedagogical competencies such as knowledge and understanding, skills, abilities, and beliefs. This finding can be viewed as novel and unique since it explains how emotional experiences accrued during pedagogical practicum contribute to building the competencies necessary for integrating PBL into teaching practices.

\section{Limitations and directions for future research}

As our study focused on reflective reports, in which the participants described their perceptions and experiences, the study could only address the PSTs' self-reported experiences and competencies. Future studies observing PSTs while PBL-based pedagogical practicum in various school contexts (e.g., during interactions with colleagues and students) may help strengthen the current study results. Additionally, interviewing PSTs, their students, and other teachers who constitute part of their network could shed additional light on the significance of emotional experiences in PBL-based pedagogical practicum.

\section{Conclusions}

The findings indicate that PSTs' immersion in the PBLbased practicum was accompanied by mostly positive emotional experiences, which were positively linked to the development of the PSTs' pedagogical competencies for implementing the PBL approach in their teaching. These findings have theoretical and practical contributions. From a theoretical perspective, we show the way in which the emotional experiences garnered during the PBL-based pedagogical practicum are linked to the development of PSTs' perceived pedagogical competencies. Nowadays, when teaching is rated as one of the most stressful professions, "there is a particularly urgent need to focus more on the role of positive emotions in sustaining teachers' positive qualities and strengths [ ...] and ability to continue to give their best in the profession - despite challenges and setbacks - and thus their sense of well being and effectiveness" (Day \& Qing, 2009, p.18).

In terms of the practical implications, the present study shows the value of integrating PBL into 
pedagogical practicum. While the value of integrating a PBL approach into disciplinary or science teaching method courses has been widely acknowledged, our work emphasises the importance of such integration into pedagogical practicum. We recommend combining clinical experience with a didactics workshop to offer a unique opportunity for PSTs to feel and understand the essence of the PBL experience. Moreover, this experience tends to prepare PSTs for implementing the PBL approach in the future. PSTs who have a history of successful implementation of PBL in their classrooms tend to be thoroughly educated to teach according to PBL pedagogical principles in a more frequent and comprehensive manner (Almulla, 2020).

\section{Acknowledgements}

We thank the preservice teachers, instructional coaches, and administrators who collaborated with us on this study. We are very grateful to Prof. Joseph Krajcik and three anonymous reviewers for their thoughtful, detailed, and constructive feedback on an earlier version of this article.

\section{Authors' contributions}

YMR contributed to the design and implementation of the research, the linguistic and statistical analyses of the data, and the manuscript writing. DT designed and directed the project, collected the data, performed content analysis, and was a major contributor in writing the manuscript. Both authors read and approved the final manuscript.

\section{Authors' information}

Not applicable.

\section{Funding}

Not applicable.

\section{Availability of data and materials}

The data that support the findings of this study are available upon reasonable request from the corresponding author. The data are not publicly available due to privacy or ethical restrictions.

\section{Declarations}

\section{Competing interests}

The authors declare that they have no competing interests.

\section{Author details}

${ }^{1}$ Faculty of Education in Science and Technology, Technion, Haifa, Israel.

${ }^{2}$ Achva Academic College, Arugot, Israel.

Received: 21 November 2020 Accepted: 10 October 2021

Published online: 05 November 2021

\section{References}

Agudo, J. D. D. M., \& Azzaro, G. (2018). Emotions in learning to teach EFL in the practicum setting: Facing the emotional dilemmas and challenges associated with professional practice. In J. D. D. M. Agudo (Ed.), Emotions in second language teaching, (pp. 365-384). Cham: Springer. https://doi.org/10.1007/ 978-3-319-75438-3_20.

Almulla, M. A. (2020). The effectiveness of the project-based learning (PBL) approach as a way to engage students in learning. SAGE Open, 10(3), 2158244020938702. https://doi.org/10.1177/2158244020938702.

Alrajeh, T. S. (2021). Project-based learning to enhance pre-service Teachers' teaching skills in science education. Univ J Educ Res, 9(2), 271-279. https:// doi.org/10.13189/ujer.2021.090202.

Anttila, H., Pyhältö, K., Soini, T., \& Pietarinen, J. (2016). How does it feel to become a teacher? Emotions in teacher education. Soc Psychol Educ, 19(3), 451-473. https://doi.org/10.1007/s11218-016-9335-0.
Anttila, H., Pyhältö, K., Soini, T., \& Pietarinen, J. (2017). From anxiety to enthusiasm: Emotional patterns among student teachers. Eur J Teach Educ, 40(4), 447464. https://doi.org/10.1080/02619768.2017.1349095.

Baran, M., \& Maskan, A. (2011). The effect of project-based learning on pre-service physics teachers' electrostatic achievements. Cypriot J Educ Sci, 5(4), 243-257.

Beauchamp, C., \& Thomas, L. (2009). Understanding teacher identity: An overview of issues in the literature and implications for teacher education. Camb J Educ, 39(2), 175-189. https://doi.org/10.1080/03057640902902252.

Beeth, M. E., \& Adadan, E. (2006). The influences of university-based coursework on field experience. J Sci Teach Educ, 17(2), 103-120. https://doi.org/10.1007/ s10972-006-9013-8.

Bellocchi, A., \& Ritchie, S. M. (2015). "I was proud of myself that I didn't give up and I did it": Experiences of pride and triumph in learning science. Sci Educ, 99(4), 638-668. https://doi.org/10.1002/sce.21159.

Bellocchi, A., Ritchie, S. M., Tobin, K., King, D., Sandhu, M., \& Henderson, S. (2014). Emotional climate and high-quality learning experiences in science teacher education. J Res Sci Teach, 51(10), 1301-1325. https:/doi.org/10.1002/tea.21170.

Bellocchi, A., Ritchie, S. M., Tobin, K., Sandhu, M., \& Sandhu, S. (2013). Exploring emotional climate in preservice science teacher education. Cult Stud Sci Educ, 8(3), 529-552. https://doi.org/10.1007/s11422-013-9526-3.

Bhattacharyya, S., Volk, T., \& Lumpe, A. (2009). The influence of an extensive inquiry-based field experience on pre-service elementary student teachers' science teaching beliefs. J Sci Teach Educ, 20(3), 199-218. https://doi.org/10.1 007/s10972-009-9129-8.

Burić, I., Slišković, A., \& Sorić, I. (2020). Teachers' emotions and self-efficacy: A test of reciprocal relations. Front Psychol, 11, 1650. https://doi.org/10.3389/fpsyg.2 020.01650 .

Buttny, R., \& Jensen, A. D. (1995). Telling problems in an initial family therapy session: The hierarchical organization of problem talk. In G. H. Morris, \& R. J. Chenail (Eds.), the talk of the clinic: Explorations in the analysis of medical and therapeutic discourse, (pp. 19-47). NY: Routledge.

Choi, J., Lee, J. H., \& Kim, B. (2019). How does learner-centered education affect teacher self-efficacy? The case of project-based learning in Korea. Teach Teach Educ, 85, 45-57. https://doi.org/10.1016/j.tate.2019.05.005.

Chu, S. K. W., Reynolds, R. B., Tavares, N. J., Notari, M., \& Lee, C. W. Y. (2017). 21 st century skills development through inquiry-based learning, (vol. 1007, pp. 978981). Singapore: Springer Singapore.

Cowie, N. (2011). Emotions that experienced English as a foreign language (EFL) teachers feel about their students, their colleagues and their work. Teach Teach Educ, 27(1), 235-242. https://doi.org/10.1016/j.tate.2010.08.006.

Craig, T. T., \& Marshall, J. (2019). Effect of project-based learning on high school students' state-mandated, standardized math and science exam performance. J Res Sci Teach, 56(10), 1461-1488. https://doi.org/10.1002/ tea.21582.

Creswell, J. W., \& Plano Clark, V. L. (2007). Designing and conducting mixed methods research. Thousand Oaks: Sage.

Creswell, J. W., \& Poth, C. N. (2016). Qualitative inquiry and research design: Choosing among five approaches. Thousand Oaks: Sage publications.

Day, C., \& Qing, G. (2009). Teacher emotions: Well being and effectiveness. In P. A. Schutz, \& M. Zembylas (Eds.), Advances in teacher emotion research, (pp. 15-31). Boston: Springer. https://doi.org/10.1007/978-1-4419-0564-2_2.

Frank, M., \& Barzilai, A. (2004). Integrating alternative assessment in a projectbased learning course for pre-service science and technology teachers. Assess Eval High Educ, 29(1), 41-61. https://doi.org/10.1080/0260293042000160401.

Fredrickson, B. L. (1998). What good are positive emotions? Rev Gen Psychol, 2(3), 300-319. https://doi.org/10.1037/1089-2680.2.3.300.

Fredrickson, B. L. (2001). The role of positive emotions in positive psychology: The broaden-and-build theory of positive emotion. Am Psychol, 56(3), 218226. https://doi.org/10.1037/0003-066X.56.3.218.

Fredrickson, B. L. (2004). The broaden-and-build theory of positive emotions. Philos Trans R Soc Lond B Biol Sci, 359(1449), 1367-1377. https://doi.org/10.1 098/rstb.2004.1512.

Fredrickson, B. L., \& Branigan, C. (2005). Positive emotions broaden the scope of attention and thought-action repertoires. Cognit Emot, 19(3), 313-332. https://doi.org/10.1080/02699930441000238.

Fredrickson, B. L., Mancuso, R. A., Branigan, C., \& Tugade, M. M. (2000). The undoing effect of positive emotions. Motiv Emot, 24(4), 237-258. https://doi. org/10.1023/A:1010796329158.

Gardiner, W., \& Robinson, K. S. (2009). Paired field placements: A means for collaboration. The New Educator, 5(1), 81-94. https://doi.org/10.1080/154 7688X.2009.10399565. 
Gkonou, C., \& Miller, E. R. (2020). 8. 'Critical Incidents' in language Teachers' narratives of emotional experience. In the emotional rollercoaster of language teaching, (pp. 131-149). Multilingual matters.

Grey, B. (2020). Recognizing the role of emotions on the teaching practices of a student teacher. Senior Scholars Day, 30. https://scholarlycommons.susqu. edu/ssd/2020/posters/30.

Grossman, P., Dean, C. G. P., Kavanagh, S. S., \& Herrmann, Z. (2019). Preparing teachers for project-based teaching. Phi Delta Kappan, 100(7), 43-48. https:// doi.org/10.1177/0031721719841338.

Halliday, M. A., \& Matthiessen, C. M. I. M. (2004). An introduction to functional grammar, (3rd ed., ). London: Edward Arnold.

Halliday, M. A. K. (1994). Introduction to functional grammar. London: Arnold.

Hong, E., Greene, M., \& Hartzell, S. (2011). Cognitive and motivational characteristics of elementary teachers in general education classrooms and in gifted programs. Gifted Child Quarterly, 55(4), 250-264. https://doi.org/10.11 77/0016986211418107.

Kavanagh, S. S., \& Rainey, E. C. (2017). Learning to support adolescent literacy: Teacher educator pedagogy and novice teacher take up in secondary English language arts teacher preparation. Am Educ Res J, 54(5), 904-937. https://doi.org/10.3102/0002831217710423.

Kihwele, J. E., \& Chuma, M. M. (2020). Understanding pre-service teachers' emotion experience during teaching practice in Tanzania: Causes, management strategies and the impacts in teaching. Environment, 11(9).

King, S. (2006). Promoting paired placements in initial teacher education. International Research in Geographical \& Environmental Education, 15(4), 370 386. https://doi.org/10.2167/irg201.0

Kokotsaki, D., Menzies, V., \& Wiggins, A. (2016). Project-based learning: A review of the literature. Improv Sch, 19(3), 267-277. https://doi.org/10.1177/136548021 6659733.

Krajcik, J. S., \& Czerniak, C. (2018). Teaching science in elementary and middle school classrooms: A project-based learning approach, (5th ed., ). New York \& London: Routledge, Taylor and Francis Group. https://doi.org/10.4324/978131 5205014

Krajcik, J. S., \& Shin, N. (2013). Project-based learning. In R. K. Sawyer (Ed.), the Cambridge handbook of learning sciences, (2nd ed., ). New York: Cambridge.

Kupferberg, I., Gilat, I., Dahan, E., \& Doron, A. (2013). Exploring the discursive positioning of a schizophrenic inpatient via method triangulation. Int J Qual Methods, 12(1), 20-38. https://doi.org/10.1177/160940691301200108.

Lavy, I., \& Shriki, A. (2008). Investigating changes in prospective teachers' views of a 'good teacher' while engaging in computerized project-based learning. J Math Teach Educ, 11(4), 259-284. https://doi.org/10.1007/s10857-008-9073-0.

Lawson, T., Çakmak, M., Gündüz, M., \& Busher, H. (2015). Research on teaching practicum-a systematic review. Eur J Teach Educ, 38(3), 392-407. https://doi. org/10.1080/02619768.2014.994060.

Loyens, S. M., Kirschner, P. A., \& Paas, F. (2012). Problem-based learning. In K. Harris, S. Graham, T. Urdan, A. Bus, S. Major, \& L. Swanson (Eds.), APA Educational PsychologyHandbook, (vol. 3, pp. 403-425). Washington DC: Application to learning and teaching, American Psychological Association.

Marshall, J. A., Petrosino, A. J., \& Martin, T. (2010). Preservice teachers' conceptions and enactments of project-based instruction. J Sci Educ Technol, 19(4), 370386. https://doi.org/10.1007/s10956-010-9206-y.

Méndez López, M. G. (2020). Emotions attributions of ELT pre-service teachers and their effects on teaching practice. Profile Issues in TeachersProfessional Development, 22(1), 25-28. https://doi.org/10.15446/profile.v22n1.78613.

Mettas, A. C., \& Constantinou, C. C. (2008). The technology fair: A project-based learning approach for enhancing problem solving skills and interest in design and technology education. Int J Technol Des Educ, 18(1), 79-100. https://doi.org/10.1007/s10798-006-9011-3.

Meyer, D. K. (2009). Entering the emotional practices of teaching. In Advances in teacher emotion research, (pp. 73-91). Boston: Springer.

Miller, E. C., \& Krajcik, J. S. (2019). Promoting deep learning through project-based learning: A design problem. Disciplinary and Interdisciplinary Science Education Research, 1(1), 1-10. https://doi.org/10.1186/s43031-019-0009-6.

Mohamed, Z., Valcke, M., \& De Wever, B. (2017). Are they ready to teach? Student teachers' readiness for the job with reference to teacher competence frameworks. J Educ Teach, 43(2), 151-170. https://doi.org/10.1080/02607476.2 016.1257509.

Muchnik-Rozanov, Y., \& Tsybulsky, D. (2019). Towards understanding the language of student teachers' reflections in the context of professional identity development. Reflective Practice: International and Multidisciplinary Perspectives, 20(4), 520-532. https://doi.org/10.1080/14623943.2019.1642188.
Nguyen, M. H. (2014). Preservice EAL teaching as emotional experiences: Practicum experience in an Australian secondary school. Australian Journal of Teacher Education, 39(8), 62-84. https://doi.org/10.14221/ajte.2014v39n8.5.

Ohana, C. (2004). Extended field experiences and cohorts with elementary science methods: Some unintended consequences. Journal of Science Teacher Education, 15(3), 233-254.

Pantić, N., \& Wubbels, T. (2010). Teacher competencies as a basis for teacher education-views of Serbian teachers and teacher educators. Teach Teach Educ, 26(3), 694-703. https://doi.org/10.1016/j.tate.2009.10.005.

Partikasari, R., \& Nurwita, S. (2019). The development of a project-based science creative learning $(\mathrm{SCL})$ as a learning proponent of student PAUD Dehasen Bengkulu University. International Journal for Educational and Vocational Studies, 1(7), 739-743. https://doi.org/10.29103/ijevs.v1i7.1735.

Reisman, A., Kavanagh, S. S., Monte-Sano, C., Fogo, B., McGrew, S. C., Cipparone, P. , \& Simmons, E. (2018). Facilitating whole-class discussions in history: A framework for preparing teacher candidates. J Teach Educ, 69(3), 278-293. https://doi.org/10.1177/0022487117707463.

Ritchie, K. C., Shore, B. M., LaBanca, F., \& Newman, A. J. (2011). The impact of emotions on divergent thinking processes: A consideration for inquiryoriented teachers. LEARNing Landscapes, 5(1), 211-225. https://doi.org/10.3 6510/learnland.v5i1.542.

Ritchie, S. M., Tobin, K., Sandhu, M., Sandhu, S., Henderson, S., \& Roth, W. M. (2013). Emotional arousal of beginning physics teachers during extended experimental investigations. J Res Sci Teach, 50(2), 137-161. https://doi.org/10.1002/tea.21060.

Sahin, A., \& Top, N. (2015). STEM students on the stage (SOS): Promoting student voice and choice in STEM education through an interdisciplinary, standardsfocused, project-based learning approach. Journal of STEM Education: Innovations \& Research, 16(3), 24-33.

Schieble, M., Vetter, A., \& Meacham, M. (2015). A discourse analytic approach to video analysis of teaching: Aligning desired identities with practice. J Teach Educ, 66(3), 245-260. https://doi.org/10.1177/0022487115573264.

Simons, M., \& Baeten, M. (2016). Student teachers' team teaching during field experiences: An evaluation by their mentors. Mentoring \& Tutoring: Partnership in Learning, 24(5), 415-440. https://doi.org/10.1080/13611267.2016.1271560.

Struyven, K., \& De Meyst, M. (2010). Competence-based teacher education: Illusion or reality? An assessment of the implementation status in Flanders from teachers' and students' points of view. Teach Teach Educ, 26(8), 14951510. https://doi.org/10.1016/j.tate.2010.05.006.

Tang, S. Y., Wong, A. K., Li, D. D., \& Cheng, M. M. (2020). Millennial generation preservice teachers' intrinsic motivation to become a teacher, professional learning and professional competence. Teach Teach Educ, 96, 103180. https:// doi.org/10.1016/j.tate.2020.103180.

Timoštšuk, l., Kikas, E., \& Normak, M. (2016). Student teachers' emotional teaching experiences in relation to different teaching methods. Educ Stud, 42(3), 269286. https://doi.org/10.1080/03055698.2016.1167674.

Trent, J. (2013). Becoming a teacher educator: The multiple boundary-crossing experiences of beginning teacher educators. J Teach Educ, 64(3), 262-275. https://doi.org/10.1177/0022487112471998.

Tsybulsky, D. (2019). The team-teaching experiences of pre-service science teachers implementing PBL in elementary school. J Educ Teach, 45(3), 244261. https://doi.org/10.1080/09589236.2019.1599505.

Tsybulsky, D., Gateneo-Kalush, M., Abuganem, M., \& Grobgeld, E. (2020). Experiences of preservice teachers exposed to project-based learning. Eur J Teach Educ, 43(3), 368-383. https://doi.org/10.1080/02619768.2019.1711052.

Tsybulsky, D., \& Muchnik-Rozanov, Y. (2019). The development of studentteachers' professional identity while team-teaching science classes using a project-based learning approach: A multi-level analysis. Teach Teach Educ, 79, 48-59. https://doi.org/10.1016/j.tate.2018.12.006.

Tsybulsky, D., \& Oz, A. (2019). From frustration to insights: Experiences, attitudes and pedagogical practices of pre-service science teachers implementing PBL in elementary school. J Sci Teach Educ, 30(3), 259-279. https://doi.org/10.1 080/1046560X.2018.1559560.

Tzifopoulos, M. (2020). Pre-service secondary teachers reflect on their pedagogical practicum experiences. International Journal of Education and Research, 2(18), 1-16.

Varma, T., \& Hanuscin, D. L. (2008). Pre-service elementary teachers' field experiences in classrooms led by science specialists. J Sci Teach Educ, 19(6), 593-614. https://doi.org/10.1007/s10972-008-9110-y.

Virtue, E. E., \& Hinnant-Crawford, B. N. (2019). "We're doing things that are meaningful": Student perspectives of project-based learning across the 
disciplines. Interdisciplinary Journal of Problem-Based Learning, 13(2), 9. https://doi.org/10.7771/1541-5015.1809.

Yuan, R., \& Lee, I. (2015). The cognitive, social and emotional processes of teacher identity construction in a pre-service teacher education programme. Res Pap Educ, 30(4), 469-491. https://doi.org/10.1080/02671522.2014.932830.

Zembylas, M. (2001). A paralogical affirmation of emotion's discourse in science teaching. In A. C. Barton, \& M. D. Osborne (Eds.), Teaching science in diverse settings: Marginalized discourses and classroom practice, (pp. 99-128). NY: Peter Lang.

Zembylas, M. (2003). Emotions and teacher identity: A poststructural perspective. Teachers and Teaching, 9(3), 213-238. https://oi.org/10.1080/13540600309378.

Zembylas, M. (2007). Emotional ecology: The intersection of emotional

knowledge and pedagogical content knowledge in teaching. Teach Teach

Educ, 4(23), 355-367. https://doi.org/10.1016/j.tate.2006.12.002.

\section{Publisher's Note}

Springer Nature remains neutral with regard to jurisdictional claims in published maps and institutional affiliations.

\section{Submit your manuscript to a SpringerOpen ${ }^{\circ}$ journal and benefit from:}

- Convenient online submission

- Rigorous peer review

- Open access: articles freely available online

High visibility within the field

- Retaining the copyright to your article

Submit your next manuscript at $\boldsymbol{\wedge}$ springeropen.com 